\title{
Caractérisation de la reproduction des cobayes locaux (Cavia porcellus L.) élevés à Kipushi et Lubumbashi (RDC)
}

Kampemba M F ${ }^{1}$, Bilolwa B $\mathbf{P}^{1}$, Ntemunyi N C $\mathbf{N}^{1}$, Mwangomb KD ${ }^{2}$ 1Département de Zootechnie, Faculté des Sciences Agronomiques, Université de Lubumbashi, BP 1825 RD Congo. 2 Centre de Recherche Agro-Alimentaire, Lubumbashi, BP 54 RD Congo. pacifiquebilolwa@gmail.com

Mots- clés : Cobaye, croissance ; paramètres de reproduction.

Keywords: Guinea pig, growth; reproduction parameters

Publication date 29/02/2020, http://m.elewa.org/Journals/about-japs/

1 RESUME

L'objectif de ce travail était d'étudier les caractéristiques de reproduction et de croissance des cobayes locaux. Soixante- six (66) cobayes ont été répartis en 2 lots (Lubumbashi et Kipushi) de 30 femelles subdivisées par lot de dix(10) élevés dans une cage de $1 \mathrm{~m}^{2}$ et 6 mâles avec un sex-ratio de 1 mâle contre 10 femelles et les saillies naturelles. Les résultats obtenus ont montré que le taux fertilité était élevé pour les femelles de Kipushi $(86,67 \%)$ par rapport à celui enregistré à Lubumbashi $(80,00 \%)$. Et le poids des femelles à la mise-bas et au sevrage n'était pas influencé par leur origine. Au niveau de la portée à la naissance ; Lubumbashi a présenté un nombre élevé $(58 \%)$ que Kipushi $(53 \%)$ pour des nés vivant. Par conséquent, le poids moyen individuel à la naissance $(70,4 \mathrm{~g})$ le poids moyen individuel au sevrage $(167,4 \mathrm{~g})$ le poids moyen par portée à la naissance $71,3 \mathrm{~g}$ et au sevrage $168,03 \mathrm{~g}$ étaient supérieures pour les animaux de Kipushi $(\mathrm{p}<0,05)$. Alors que la portée au sevrage, le nombre de petits par sevrage était semblable entre sites $(P>0,05)$. En plus, la productivité numérique et pondérale était élevée pour les femelles de Kipushi $(1,57)$ et faible pour celles de Lubumbashi $(1,17)$. L'évolution du poids des cobayes variaient en fonction du site. Ces résultats sur les paramètres de reproduction dévoilent l'existence d'une grande variabilité entre ces deux populations locales, ce qui crée une occasion pour l'amélioration génétique des cobayes locaux.

Characterization of the reproduction of local guinea pigs (Cavia porcellus L.) raised in Kipushi and Lubumbashi (DRC)

\section{ABSTRACT}

The objective of this work was to study the reproductive and growth characteristics of local guinea pigs. Sixty-six (66) guinea pigs were divided into 2 lots (Lubumbashi and Kipushi) of 30 females subdivided by lot of ten (10) reared in a $1 \mathrm{~m} 2$ cage and 6 males with a sex ratio of 1 male versus 10 females and natural projections. The results obtained showed that the fertility rate was high for Kipushi females (86.67\%) compared to that recorded in Lubumbashi $(80.00 \%)$. Moreover, the weight of the females at birth and at weaning was not influenced by their origin. At the level of the litter at birth, Lubumbashi presented a higher number $(58 \%)$ than Kipushi $(53 \%)$ for born babies. Therefore, the average individual weight 
at birth (70.4g) the average individual weight at weaning $(167.4 \mathrm{~g})$ the average weight per litter at birth $71.3 \mathrm{~g}$ and at weaning $168.03 \mathrm{~g}$ were higher for the Kipushi animals $(\mathrm{p}<0,05)$. While the litter at weaning, the number of pups per weaning was similar between sites $(\mathrm{P}>$ 0.05). In addition, numerical and weight productivity was high for Kipushi females (1.57) and low for Lubumbashi females (1.17). The evolution of the weight of the guinea pigs varied according to the site. These results on reproductive parameters reveal the existence of great variability between these two local populations, which creates an opportunity for the genetic improvement of local guinea pigs. 